\title{
First records of Rhicnoda natatrix and Rhicnoda rugosa (Blattodea: Blaberidae) from Nepal and India (Maharashtra) with notes on habitat quality
}

\author{
Hasko Nesemann ${ }^{1}$, Ram Devi T. Shah ${ }^{2}$, Deep Narayan Shah ${ }^{2} \&$ Subodh Sharma ${ }^{3}$ \\ ${ }^{1,3}$ Aquatic Ecology Center, Kathmandu University, Dhulikhel, Nepal \\ ${ }^{2}$ Hindu Kush Himalayan Benthological Society, Kausaltar, Nepal \\ Email: ${ }^{1}$ hnesemann2000@yahoo.co.in
}

Date of publication (online): 26 January 2010 Date of publication (print): 26 January 2010 ISSN 0974-7907 (online) | 0974-7893 (print)

Editor: Prem Budha

\section{Manuscript details:}

Ms \# 02281

Received 03 August 2009

Final received 09 November 2009

Finally accepted 03 December 2009

Citation: Nesemann, H., R.D.T. Shah, D.N. Shah \& S. Sharma (2010). First records of Rhicnoda natatrix and Rhicnoda rugosa (Blattodea: Blaberidae) from Nepal and India (Maharashtra) with notes on habitat quality. Journal of Threatened Taxa 2(1): 648-652.

Copyright: (c) Hasko Nesemann, Ram Devi T. Shah, Deep Narayan Shah \& Subodh Sharma 2010. Creative Commons Attribution 3.0 Unported License. JoTT allows unrestricted use of this article in any medium for non-profit purposes, reproduction and distribution by providing adequate credit to the authors and the source of publication.

Author Details: All the authors specialize in aquatic Macro-Invertebrate diversity and biological water quality monitoring in different ecoregions of the Central Himalayas with special emphasis on applicable keys for detailed identification of the regional fauna.

Author Contribution: HN conducted the field study and wrote up the paper as well as illustrated the species. The other authors contributed by writing the paper as well as conducted field and lab study.

Acknowledgements: Thanks are due to Andreas Dorsch (Lorsbach, Germany) for kindly helping in the literature search and especially for the original description of Shelford (1907).

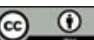

(10)

OPEN AGCESS | FREE DOWNLOAD
Abstract: Two species of cockroaches were collected from aquatic habitats of undisturbed natural forest streams in Nepal and India (Maharashtra): Rhicnoda natatrix and Rhicnoda rugosa. Nymphs and adults are depicted and field observations of microhabitat and behavior described. Taxa lists of accompanying macroinvertebrate fauna are given, and water quality class is calculated using three biotic scoring systems. $R$. natatrix is a true aquatic species with amphibious lifestyle in the eulittoral of springs (Crenon) and streams (Rhithron) of excellent and good water quality classes I and II. $R$. rugosa is a predominantly terrestrial species that also colonizes the banks of water bodies and appears in between aquatic fauna. These species cannot be classified using the traditional habitat system.

Keywords: Aquatic fauna, ecological habitat, water quality

\section{INTRODUCTION}

Fossil ancestors show the order Blattodea to be among the oldest extant groups of insects. "Blattoid" insects were already highly diversified in the Paleozoic and cockroaches (Eublattoidea) were dominant terrestrial insects in the Carboniferous and Permian (Beier 1967 - more recently true modern cockroach origins have been dated to the Triassic/Jurassic; Wichard et al. 1995). At present 4560 living species are known, but only a few enter aquatic zones. Fossil aquatic cockroaches are found from the Mesozoic, while extant aquatic cockroaches are known only from South Asia, South-East Asia and Japan. They share some characters with "living fossils" in belonging to geologically ancient taxa having Mesozoic characteristics and formerly wide distribution ranges, like the relict dragonflies (Anisozygoptera: Epiophlebiidae, Tab. 3, 4). Information in the literature is sparse. Only a few papers were published in the years 1900 to 1921 when the present taxa were still regarded as members of the order Orthoptera (Annandale 1900, 1906; Green 1902; Shelford 1907, 1909; Takahashi 1921). Findings of aquatic Epilamprinae in a Malaysian stream were published by Bishop (1973) who identified three genera. In the more recent taxonomical literature of aquatic macro-invertebrates Blattodea are briefly mentioned only by Ward (1992: 28), Hutchinson (1993: 569) and Dudegon (1999: 511-512).

From the Indian subcontinent the first published record (Annandale 1906: 105) described unidentified aquatic cockroaches in Jharkhand. Annandale collected a female nymph on 04 March 1905 "while turning over stones in a small jungle stream on a hill near Chakardharpur in Chota Nagpur". This and few other specimens prior to the description Rhicnoda natatrix are undoubtedly lost (Shelford 1907: 225). During the present study aquatic cockroaches were found in Maharashtra and Nepal. In both states no lists of cockroaches exists. Thus our records appear to be new for the country and the Himalayan region. Mandal $(2003,2006)$ did not mention the presence of Rhicnoda species for the fauna of Sikkim and Arunachal Pradesh. Most of the scattered published literature includes only terrestrial samples without specific habitat information. Aquatic forms might have been simply overlooked, because no particular research was done.

\section{Materials and Methods}

During different stream surveys in Nepal and India undertaken by the first three authors, Blattodea were discovered in qualitative samples and considered to be accidentally terrestrial forms. After recognizing them as true semi-aquatic and aquatic fauna in the field, thorough research was done to obtain more knowledge on these virtually unknown animals. Field collection of aquatic macroinvertebrates was done by the hand pickup method and with hand nets (mesh size $0.5 \mathrm{~mm}$ ) on various occasions. The relative abundance of each taxon was estimated in field observations and [after 
Table 1. Investigated Specimens of Rhicnoda spp. from Nepal and India

\begin{tabular}{|c|c|c|}
\hline $\begin{array}{l}\text { Locality/Species } \\
\text { rugosa }\end{array}$ & $\begin{array}{l}\text { Rhicnoda natatrix } \\
\text { [body length of } \\
\text { preserved } \\
\text { specimen] }\end{array}$ & $\begin{array}{l}\text { Rhicnoda } \\
\text { [body length of } \\
\text { preserved } \\
\text { specimen] }\end{array}$ \\
\hline $\begin{array}{l}\text { Sim-Khola, Daman } \\
\text { (Middle reach) }\end{array}$ & $\begin{array}{l}8.5 \mathrm{~mm} \text { nymph } \\
9.5 \mathrm{~mm} \text { nymph } \\
10.0 \mathrm{~mm} \text { nymph } \\
10.5 \mathrm{~mm} \text { nymph } \\
10.5 \mathrm{~mm} \text { nymph }\end{array}$ & \\
\hline First tributary of Sim-Khola, Daman & $9.0 \mathrm{~mm}$ nymph & \\
\hline Dhobi Khola, Bagmati watershed & $\begin{array}{l}9.5 \mathrm{~mm} \text { nymph } \\
\text { (not preserved) }\end{array}$ & $\begin{array}{l}10.5 \mathrm{~mm} \text { nymph } \\
36.5 \mathrm{~mm} \text { female } \\
\text { adult }\end{array}$ \\
\hline Sungure Khola, Godavari & $8.5 \mathrm{~mm}$ nymph & \\
\hline Godavari Khola, Godavari & $10.5 \mathrm{~mm}$ juvenile & $\begin{array}{l}11.5 \text { nymph (not } \\
\text { preserved) }\end{array}$ \\
\hline Jakeshwori Khola, Melamchi & $12.0 \mathrm{~mm}$ nymph & \\
\hline Pench forest stream, spring region & $\begin{array}{l}14.0 \mathrm{~mm} \text { nymph } \\
10.5 \mathrm{~mm} \text { nymph }\end{array}$ & \\
\hline Pench, Ambakori Totladoah & $\begin{array}{l}13.0 \mathrm{~mm} \text { nymph } \\
18.5 \mathrm{~mm} \text { male adult } \\
22.5 \mathrm{~mm} \text { male adult }\end{array}$ & \\
\hline $\begin{array}{l}\text { Forest stream, } \\
\text { Seti Watershed, Pokhara valley }\end{array}$ & & $23.0 \mathrm{~mm}$ male adult \\
\hline Total number of specimens & 14 & 3 \\
\hline
\end{tabular}

sorting and identification in laboratory] finally described in terms of abundance according to Mason (1981) and Chapman (1992). Water quality and (ecological) River quality classes were calculated following the commonly applied biotic scoring systems of South Asia: NEPBIOS - Nepalese Biotic Score (Sharma 1996; Sharma \& Moog 2005), GRS-Bios - Ganga River System Biotic Score (Nesemann 2006), HKHBIOS Hindu-Kush Himalayan Biotic Score (Ofenböck et al. 2008).

Two species of cockroaches were identified from aquatic collections of forest streams and the Eulittoral of the stream banks. Identity was confirmed with the help of an original description received from University Library Saarbrücken, Germany. The only color figure of an aquatic species was published by Shelford (1910) showing an adult specimen of Rhicnoda natatrix on Image $2 a$. Other sources are the photographs published by Bragg (http://blattodea-culturegroup.org). Figures of four specimens were originally drawn by the first author (Images 1 \& 2).

\section{RESULTS}

The genus Rhicnoda includes four species of Oriental or Indo-Malayan region. Rhicnoda rugosa has the largest known distribution. The remaining three species ( $R$. natatrix, $R$. desidiosa, $R$. spinulosa) are relatively unknown, although $R$. natatrix was in culture. In books this species is mentioned as water-cockroach only by Beier (1967). The material mentioned below is deposited in the collection of the Zoological Survey of India, Gangetic plains regional station, Patna, Bihar and one is deposited in Hindu Kush Himalayan Benthological Society, Nepal

Altogether nineteen specimens from nine localities were available. Their body length without antennae and appendices was measured and listed in Table 1. The accompanying aquatic invertebrate fauna was studied in eight habitats and their taxa lists are compiled in Tables 3 and 4.

\section{Rhicnoda natatrix Shelford, 1907}

Material: 15 specimens from 6 localities.

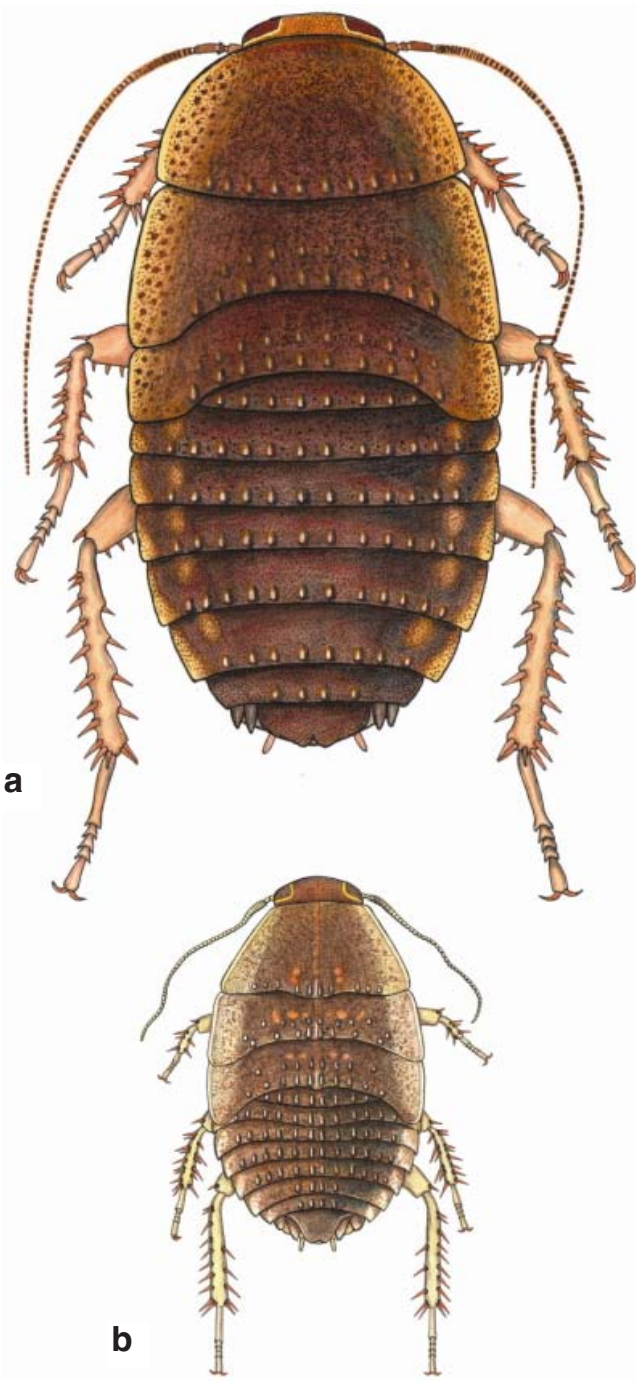

Image 1. Blaberidae: Rhicnoda natatrix. a - adult male, length, $22.5 \mathrm{~mm}$, India, Maharashtra, Pench: Ambakhori-Totladoah forest stream; b - nymph, length, 10.0mm, Nepal, Makwanpur, Sim-Khola, middle reach.

Nepal: 5 nymphs, Mahabharat range, Makwanpur district, Daman, Sim-Khola (middle reach), November 2007.

Nepal:1 nymph, Mahabharat range, Makwanpur district.

Daman, First tributary of Sim-Khola, November 2007

Nepal: 1 nymph, Shivapuri National Park, Bagmati watershed, Dhobi Khola, May 2007

Nepal: 1 nymph, Bagmati watershed,Naudhara community forest, Sungure Khola, May 2007

Nepal: 1 nymph, Bagmati watershed, Naudhara community forest, Godavari Khola, May 2007

Nepal: 1 nymph, Indrawati watershed, Melamchi, Jakeshwori forest stream, November 2009

India: 2 nymphs, Pench National Park, forest stream, spring region, November 2008.

India: 2 adult males, 1 nymph, Pench National Park, Ambakori Totladoah, November 2008.

Rhicnoda rugosa Brunner von Wattenwyl, 1865

Material: 4 specimens from 3 localities.

Nepal: 1 adult male, Pokhara Valley, Seti watershed, March 2007. 
Table 2. Characteristics of different stream habitats with Rhicnoda natatrix in Nepal and India

\begin{tabular}{|c|c|c|c|c|c|}
\hline Locality & $\begin{array}{l}\text { Biocoenotic Zone, } \\
\text { Typology }\end{array}$ & Taxa No. & $\begin{array}{l}\text { Water Quality } \\
\text { ClassNEPBIOS }\end{array}$ & $\begin{array}{l}\text { Water Quality } \\
\text { ClassGRS-BIOS }\end{array}$ & $\begin{array}{l}\text { Water Quality } \\
\text { ClassHKHBIOS }\end{array}$ \\
\hline Sim Khola midstream & Metarhitron & 29 & I & 1 & I \\
\hline First Tributary of Sim Khola & Epirhithron & 42 & I & I & I \\
\hline Tributary of Ghatte Khola* & Epirhithron & 10 & I & I & I \\
\hline Pench, forest spring stream & Hypocrenon & 12 & I & I & I \\
\hline Ambakhori-Totladoah forest stream* & Metarhithron-Hyporhithron & 11 & III & II & IV \\
\hline Average & & 20.8 & 1.4 & 1.2 & 1.6 \\
\hline
\end{tabular}

Table 3. Macro-invertebrate fauna of different Rhicnoda-habitats in Nepal

\begin{tabular}{|c|c|c|c|c|c|c|c|c|c|c|c|c|c|}
\hline \multirow[b]{2}{*}{ Order / Family } & \multirow[b]{2}{*}{ Genus species } & \multicolumn{5}{|c|}{ Abundance per Locality } & \multirow[b]{2}{*}{ Order / Family } & \multirow[b]{2}{*}{ Genus species } & \multicolumn{5}{|c|}{ Abundance per Locality } \\
\hline & & I & II & III & IV & V & & & I & II & III & IV & V \\
\hline Order: Ephemeroptera & & & & & & & Coenagrionidae & & & 1 & & & \\
\hline Baetidae & Baetis sp. & 2 & 1 & 1 & 2 & 2 & Calopterygidae & & & 1 & & & \\
\hline & Baetiella sp. & 1 & & & & & Order: Diptera & & & & & & \\
\hline & Pseudocloeon sp. & 2 & & & & & Limoniidae & & 1 & 2 & 2 & 1 & 1 \\
\hline Heptageniidae & & & & 2 & & 1 & Athericidae & & & 1 & 2 & 2 & 1 \\
\hline & Iron sp. & 1 & & & & & Ceratopogonidae & & & 1 & 1 & & \\
\hline & Ecdyonurus sp. & 2 & & & & & Chironomidae & Chironominae & & & & 1 & 1 \\
\hline & Notacanthurus sp. & 2 & 1 & & & & & Orthocladiinae & & 2 & 1 & & 2 \\
\hline Caenidae & & & & & & 1 & & Tanypodinae & & 1 & & 1 & \\
\hline Ephemeridae & Ephemera sp. & 1 & 1 & 2 & 1 & 2 & & Tanytarsini & & 2 & & & \\
\hline Ephemerellidae & & & & 3 & & 3 & Dolichopodidae & & & 1 & & & 1 \\
\hline Leptophlebiidae & & & & 2 & & & Sciaridae & & & 2 & & 1 & 1 \\
\hline & Indialis $s p$. & 1 & & & & & Tabanidae & & & 1 & 1 & & \\
\hline & Habrophebiodes sp. & 1 & & & & & Simuliidae & & 1 & 2 & & & 3 \\
\hline & Serratella sp. & 1 & & & & & Tipulidae & & 1 & 2 & 4 & 4 & 2 \\
\hline Order: Plecoptera & & & & & & & Empididae & & & & & 1 & 1 \\
\hline Perlidae & & & & 4 & 3 & & Muscidae & & & & & & 1 \\
\hline & Kamimura sp. & 2 & 2 & & & & Scatophagidae & & & & & & 1 \\
\hline & Tyloperla sp. cf. & 1 & & & & & Culicidae & & & & & & 1 \\
\hline Perlodidae & & & 1 & & & & Order: Blattodea & & & & & & \\
\hline Nemouridae & & & & 3 & 3 & 2 & Blaberidae & Rhicnoda natatrix & 1 & 2 & 1 & 1 & \\
\hline & Amphinemoura sp. & 1 & & & & & & Rhicnoda rugosa & & & 1 & & 1 \\
\hline & Mesonemoura sp. & & 2 & & & & Order: Chilopoda & & & 1 & & & \\
\hline Peltoperlidae & & 2 & & & & & Order: Oniscoidea & & & 1 & & & \\
\hline Order: Trichoptera & & & & & & & Order: Decapoda & & & & & & \\
\hline Hydropsychidae & Hydropsyche sp. & 2 & 3 & 2 & 3 & & Potamidae & Himalayapotamon spec. & 1 & & & & 1 \\
\hline Odontoceridae & & 1 & 1 & & & & Order: Tricadida & & & & & & \\
\hline Philopotamidae & & & 3 & 2 & 2 & & Planariidae & & & 3 & 2 & & 2 \\
\hline Limnephilidae & Potamophylax sp. & & 2 & & & & Order: Lumbricina & & & & & & \\
\hline Lepidostomatidae & & & & 2 & 4 & 1 & Megascolecidae & Perionyx fluviatilis & 1 & 1 & 2 & & 1 \\
\hline & Paraplegopteryx sp. & 1 & 2 & & & & Order: Tubificina & & & & & & \\
\hline Helicopsychidae & & & & 2 & & & Tubificidae & & & & & & 2 \\
\hline Polycentropodidae & & & 2 & & & & Order: Hirudinida & & & & & & \\
\hline Glossosomatidae & & & & & & 1 & Salifidae & Barbronia nepalensis & & & 1 & & \\
\hline Rhyacophilidae & & 2 & & & 1 & & Order: Prosobranchia & & & & & & \\
\hline Order: Lepidoptera & & & & & & & Pomatiopsidae & Tricula montana & & & & 2 & 1 \\
\hline Pyralidae & & & & 1 & & & & Tricula godavarierensis & & & & & 1 \\
\hline Order: Megaloptera & & & & & & & & Erhaia suguriensis & & & & 2 & \\
\hline Corydalidae & & & & 1 & & & Order: Basommatophora & & & & & & \\
\hline Order: Coleoptera & & & & & & & Planorbiidae & Segmentina calatha & & 1 & & & \\
\hline Elmidae & & & & 1 & 1 & 1 & Order: Veneroida & - & & & & & \\
\hline & Stenelmis sp. & 1 & 1 ‘ & & & & Sphaeriidae & Pisidium casertanum & & 2 & & & \\
\hline & Grouvelinus sp. & 2 & 2 & & & & & Pisidium atkinsonianum & & & 2 & & 1 \\
\hline Psephenidae & & & & 1 & 3 & 1 & & Pisidium annandalei & & & & 2 & \\
\hline Scirtidae & & 2 & 2 & 1 & 2 & 1 & Total number of taxa & & 29 & 42 & 33 & 31 & 39 \\
\hline Hydraenidae & & 1 & 1 & & & & & & & & & & \\
\hline Dryopidae & & & 1 & & & & & & & & & & \\
\hline Dytiscidae & & & 1 & 2 & 1 & & & & & & & & \\
\hline Larvae indet. & & & & & 1 & & & & & & & & \\
\hline Order: Heteroptera & & & & & & & & & & & & & \\
\hline Hebridae & & 1 & & & & & & & & & & & \\
\hline Mesoveliidae & & & 1 & & & & & & & & & & \\
\hline Gerridae & & & & & & 1 & & & & & & & \\
\hline Order: Odonata & & & & & & & & & & & & & \\
\hline Epiophlebiidae & Epiophlebia laidlawi & 2 & 2 & & & & & & & & & & \\
\hline Gomphidae & & & 1 & 1 & 1 & 1 & & & & & & & \\
\hline Corduliidae & & & & & 1 & & & & & & & & \\
\hline Libellulidae & & & & & & 1 & & & & & & & \\
\hline Macromiidae & & & & & & 1 & & & & & & & \\
\hline Cordulegastridae & & & & 1 & 1 & 1 & & & & & & & \\
\hline Aeshnidae & & & 1 & 2 & 1 & & & & & & & & \\
\hline Euphaeidae & & & & 2 & 3 & 2 & & & & & & & \\
\hline
\end{tabular}


Table 4. Macro-invertebrate fauna of different Rhicnodahabitats in India (Pench).

\begin{tabular}{|c|c|c|c|}
\hline \multirow[b]{2}{*}{ Order / Family } & \multirow[b]{2}{*}{ Genus species } & \multicolumn{2}{|c|}{$\begin{array}{l}\text { Abundance per } \\
\text { Locality }\end{array}$} \\
\hline & & VI & VII \\
\hline \multicolumn{4}{|l|}{ Order: Odonata } \\
\hline Libellulidae & & 1 & \\
\hline Platycnemididae & & Adults & \\
\hline Gomphidae & cf. Nihonogomphus sp. & & 2 \\
\hline \multicolumn{4}{|l|}{ Order: Heteroptera } \\
\hline Naucoridae & & 1 & 1 \\
\hline Veliidae & Microvelia sp. & 3 & 3 \\
\hline \multicolumn{4}{|l|}{ Order: Coleoptera } \\
\hline Dytiscidae & & 2 & 2 \\
\hline Scirtidae & & 1 & \\
\hline \multicolumn{4}{|l|}{ Order: Diptera } \\
\hline Athericidae & & 1 & \\
\hline Chironomidae & Chironominae & & 1 \\
\hline Tipulidae & & Adults & \\
\hline \multicolumn{4}{|l|}{ Order: Blattodea } \\
\hline Blaberidae & Rhicnoda natatrix & 2 & \\
\hline \multicolumn{4}{|l|}{ Order: Decapoda } \\
\hline Atyidae & & 3 & \\
\hline Potamidae & & 2 & 1 \\
\hline \multicolumn{4}{|l|}{ Order: Prosobranchia } \\
\hline \multirow[t]{3}{*}{ Thiaridae } & Thiara lineata & & 2 \\
\hline & Thiara scabra & & 1 \\
\hline & Melanoides tuberculatus & & 2 \\
\hline \multicolumn{4}{|l|}{ Order: Lumbricina } \\
\hline Megascolecidae & & 2 & 1 \\
\hline Total Number of Taxa & & 12 & 11 \\
\hline
\end{tabular}

Nepal: 1 nymph, Bagmati watershed, Naudhara community forest, Godavari Khola, May 2007.

Nepal: 1 adult female, 1 nymph, Shivapuri National Park, Bagmati watershed, Dhobi Khola May 2007.

\section{Habitat characteristics}

The localities of Rhicnoda spp. in Nepal are mostly situated in the eco-region of the Eastern Himalayan Broadleaf forests. Their faunal composition of aquatic macro-invertebrates with abundance is compiled in Table 3 . The identification of the material turns out the sympatric occurrence of Rhicnoda natatrix Shelford, 1907 and Rhicnoda rugosa Brunner von Wattenwyl, 1865 in the Shivapuri hills of the Bagmati watershed at the southern slope of Shivapuri (Kathmandu Valley). These localities in natural mixed forest dominated by Chir Pine (Pinus roxburgii) are at $1600-1700 \mathrm{~m}$ in altitude. Remarkable is the occurrence of Rhicnoda natatrix in the Mahabharat range at 2450 meters, because this is also one of the best known habitats of the Himalayan relict dragonfly (Epiophlebia laidlawi). Two localities of Sim-Khola are from natural forest stream in dense mixed forest dominated by Brown Oak (Quercus semecarpifolia) and Blue Pine (Pinus wallichiana). All mentioned water bodies represent undisturbed natural small to medium sized streams with water quality class I; and river quality class I.

In India cockroaches were found in the Central Deccan Plateau Dry Deciduous Forests dominated by teak, Tectona grandis. The faunal composition of aquatic macroinvertebrates for two localities with abundances are compiled in Table 4. Both localities in the Pench National Park in Maharashtra are situated in dense pristine mixed forests (jungle) of the Satpuri-Maikal hill range in 425 to $630 \mathrm{~m}$ altitude. In the Pench forest spring stream dense fish populations occur from the spring pool downstream. Pelal sediments (mud and silt) are with reductions in some places. Nevertheless, water quality class I (excellent) is based on three different biotic

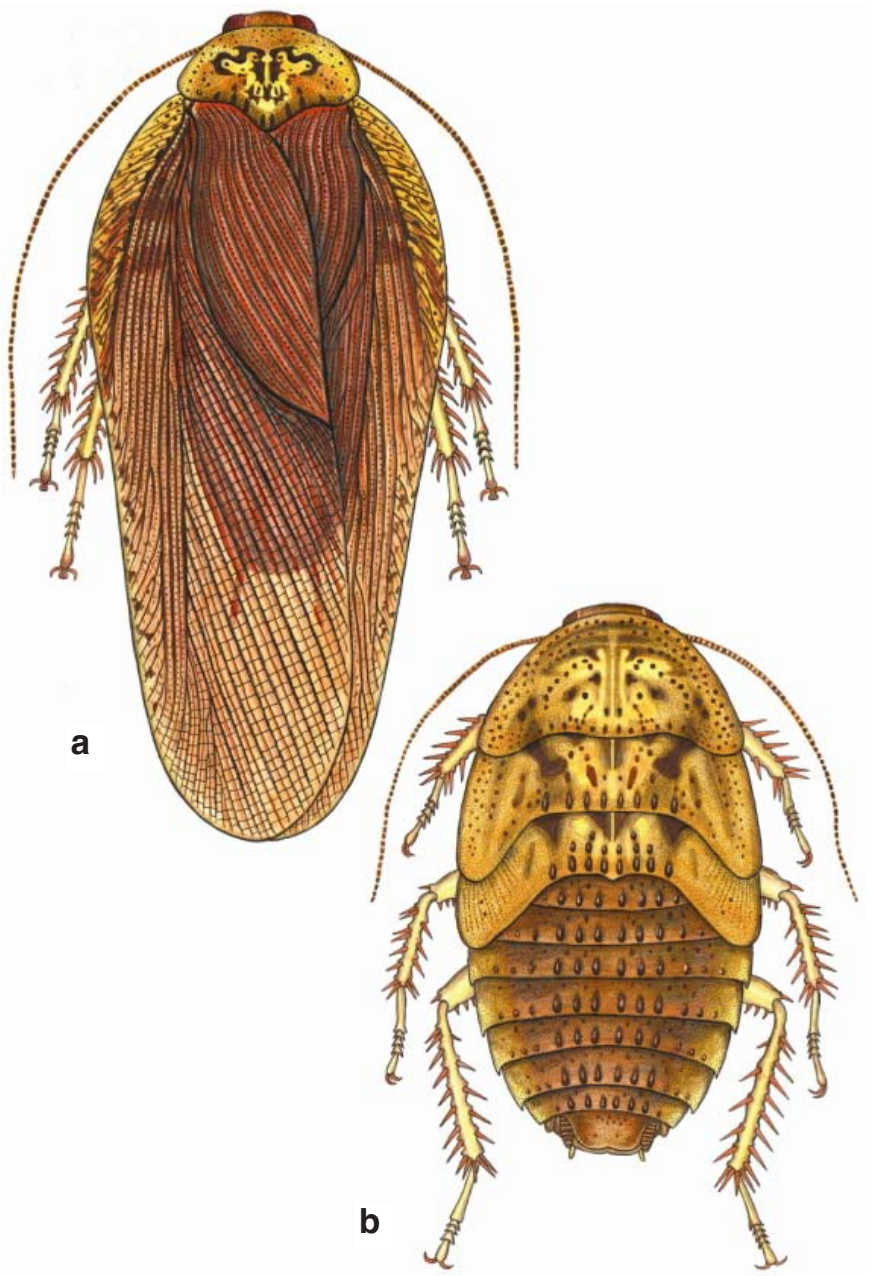

Image 2. Blaberidae: Rhicnoda rugosa. a - adult female, length $36.5 \mathrm{~mm}$, Nepal, Shivapuri, DhobiKhola; b - adult male length, 23.0mm, Nepal, Seti Nadi, Tributary in Pokhara Valley.

scores, because mostly sensitive taxa were found. The lower number of taxa in three sampling sites is caused by different time schedule, sampling methods and weather conditions. Two streams marked with * were only roughly sited and the faunal inventory could not be covered. Therefore the water quality class of Ambakhori-Totladoah forest stream (left tributary of Pench River, downstream Ambakhori waterfall) may not reflect the excellent situation, since only a few taxa of Gomphidae, Blaberidae, Potamidae and Gastropoda could be collected.

\section{Ecological field observations}

Rhicnoda natatrix was found benthic and under stones of the shoreline. Specimens were observed swimming and diving. They were running quickly into and out of water during daytime. The micro-habitats are downstream from rapids and waterfalls. Only larvae and wingless (= aptery) females were seen. The winged (= macroptery) male specimen of Rhicnoda rugosa was collected from the shoreline outside the water under large boulders. The two species can be easily distinguished in the field by their dorsal color pattern. Rhicnoda natatrix is uniform-colored dark red-brown or pinkish brown. Rhicnoda rugosa has always a central metameric color pattern with light marginal fields and much darker median stripe. This is already visible in the nymphs and allows readily making 
preliminary field identification.

The habitats of the two species are different but overlapping along the water courses. Rhicnoda natatrix (Images 1a \& 1b) appears aquatic to semi-aquatic species. Rhicnoda rugosa (Images $2 \mathrm{a} \& 2 \mathrm{~b}$ ) is a predominantly terrestrial species of humid forest habitats that can also enter semi-aquatic zones of eulittoral and tolerate some duration under water.

Locality No. I: Sim Khola (middle reach) southeast of Simbhanjayang, Daman, Nepal, Sampling date: 10.11.2007, Altitude: $\sim 2310 \mathrm{~m}$.

Locality No. II: First Tributary of Sim Khola, Daman, Sampling date: 10.11.2007, Altitude: $2385 \mathrm{~m}$.

Locality No. III: Dhobi Khola, Taulung, Chapali-Bhadrakali (Shivapuri National Park), Kathmandu, Site Code: N03DH011, Sampling date: May 2007, Altitude: $1750 \mathrm{~m}$.

Locality No. IV: Sungure Khola (Upstream of Godavari Khola), Bagmati Watershed, Naudhara community forest, Lalitpur, Site Code: N03GO011, Sampling date: May 2007, Altitude: 1700m. Locality No. V: Godavari Khola, Inside Botanical Garden, Bagmati Watershed, Naudhara community forest, Lalitpur, Nepal Site Code: N03G002, Sampling date: May 2007, Altitude: $\sim 1500 \mathrm{~m}$.

Locality No. VI: Jakeshwori khola, Indrawati watershed, Melamchi, Nepal, Site Code:N03JA013, Sampling date: November 2009,

Locality No. VII: Pench, forest spring stream (Tiger Reserve), Maharashtra, India, 13.11.2008.

Locality No. VIII: Pench, Ambakhori-Totladoah forest stream, waterfalls near small Mahadev Temple, (Tiger Reserve), Maharashtra, India, 13.11.2008.

Locality No.IX: Forest stream, Seti Watershed, Pokhara valley, Nepal, March 2007

\section{References}

Annandale, N. (1900). Notes on Orthoptera in the Siamese Malay State. Entomological Records 12: 75.

Annandale, N. (1907). Notes on the Freshwater Fauna of India. No. III. An Indian Aquatic Cockroach and Beetle Larva. Journal \& Proceedings of the Asiatic Society of Bengal, New Series 2 (4): 105-107.

Beier, M. (1967). Schaben (Blattariae). Die Neue Brehm-Bücherei. Heft 379, A. Ziemsen Verlag, Wittenberg Lutherstadt, 38pp.

Bishop, J.E. (1973). Limnology of a small Malayan River Sungai Gombak. Monographiae Biologicae, Dr. W. Junk B.V., Publishers. The Hague 22: 1-485.

Brunner von Wattenwyl, C. (1865). Nouveau système des blattaires. G. Braumüller, Vienne, 426pp.
Chapman, D. (1992). Water Quality Assessment. A guide to the use of biota, sediments and water in environmental monitoring. Chapman \& Hall, London, $x x+585 p p$.

Dudegon, D. (1999). Tropical Asian Streams: Zoobenthos, Ecology and Conservation. Hong Kong University Press, HKU: 291-316.

Green, E.E. (1902). Aquatic Orthoptera in Ceylon. Entomological Mon. Mag. 38: 214-215.

Hutchinson, G.E. (1993). A Treatise on Limnology. Volume 4. The Zoobenthos. John Wiley \& Sons, New York, Chichester, $\mathrm{xx}+944 \mathrm{pp}$.

Mandal, S.K. (2003). Insecta: Blattariae, pp. 227-237. In: The Zoological Survey of India, State Fauna Series 9 (Part-2), Fauna of Sikkim.

Mandal, S.K. (2006). Blattaria (Dictyoptera), pp. 175-190. In: The Zoological Survey of India, State Fauna Series 13(Part-2), Fauna of Arunachal Pradesh.

Mason, C.F. (1981). Biology of Freshwater Pollution. Longman, Harlow, 250pp.

Nesemann, H. (2006). Aquatic non-insect macro-invertebrate fauna and their role in bio-monitoring of the Ganga River System (With Illustrated Key Including 679 Figures). Dissertation Submitted for the partial fulfillment of the requirements for the Master of Science by Research degree in Environmental Science, Department of Environmental Science and Engineering, School of Science, Kathmandu University, 135pp.+68 plates.

Ofenböck, T., O. Moog \& S. Sharma (2008). Development and application of the HKH Biotic Score to assess the river quality in the Hindu Kush-Himalaya region, pp. 17-32. In: Moog, O., Hering, D., Sharma, S., Stubauer, I. and T. Korte (eds.): Proceedings of the Scientific Conference Rivers in the Hindu Kush-Himalaya The Ecology \& Environmental Assessment, ISBN 978-3-00024806-1.

Sharma S. (1996). Biological assessment of water quality in the rivers of Nepal. PhD Dissertation. Applied Natural Science, Department of Sanitary Engineering and Water Pollution Control, Institute of Water Provision, Water Ecology and Waste Management, BOKU - University of Natural Resources and Applied Life Sciences, Vienna, Austria, 257+cxxxivpp.

Sharma, S. \& O. Moog (2005). A reference based "Nepalese Biotic score" and its application in the midland hills and lowland plains for the river quality assessment and management. IBDC Book, Army Printing Press, Lucknow, Chapter 41, 356-362pp.

Shelford, R. (1907). Aquatic Cockroaches. Zoologist 1907: 221-226.

Shelford, R. (1909). Notes on some amphibious cockroaches. Records of the Indian Museum Calcutta 3: 125-127.

Shelford, R. (1910). Orthoptera. Familie Blattidae. Subfam. Epilamprinae. With two color plate. In: Wytsman, P. (ed.): Genera Insectorum. Bruxelles, Fascicule 101: 1-21.

Takahashi, R. (1921). Orthoptera and water. Transactions of the Sapporo Natural History Society 8: 85-100.

Ward, J.V. (1992). Aquatic Insect Ecology. 1. Biology and Habitat. John Wiley \& Sons, Inc. New York, 438pp.

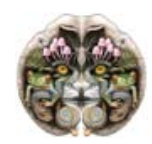

